\title{
Analisis Residu Antibiotik Serta Kualitas Daging dan Hati Ayam Broiler Di Kabupaten Pidie Jaya Provinsi Aceh
}

\author{
Antibiotic Residue Analysis of Chicken Meat and Liver in Pidie Jaya, Aceh Province \\ Masrianto $^{1}$, I. I. Arief ${ }^{2}$, \& E. Taufik ${ }^{2}$ \\ ${ }^{1}$ Mahasiswa Magister Ilmu Produksi dan Teknologi Peternakan, Fakultas Peternakan, IPB Universty \\ ${ }^{2}$ Departemen Ilmu Produksi dan Teknologi Peternakan, Fakultas Peternakan, IPB University \\ Jln. Agatis Kampus IPB University Dramaga, Bogor 16680 \\ Email koresponden author: Irmaisnafia@gmail.com
}

\begin{abstract}
Chicken is one of the sources of animal protein which is widely consumed in Indonesia. The quality and safety of chicken meat for human health need to be considered. This chicken meat should be free from antibiotic residues. This study was aimed to determine antibiotic residues and qualty of meat and liver of chicken. The study used a total sample of 156 including 52 breast meat, 52 thigh and 52 liver obtained from 5 groups of chicken breeders in 5 sub districts of Pidie Jaya district (Meureudu,Ulee Gle, Bandar Baru, Trienggadeng and Meurah Dua). The pH average from tested chicken was found to be between 5.8 and 5.9. Cooking loss was found to be ranged from $33.28 \%$ to $39.42 \%$. Antibiotic residues were tested by bioassay method. The Results showed that antibiotic residues were not detected in meat and liver except peniciline residues wich were found in breast meat, thigh and liver of chicken from Trienggadeng sub district.
\end{abstract}

Keywords: Biossay method, chicken meat, chicken liver, Pidie Jaya.

\begin{abstract}
ABSTRAK
Ayam adalah salah satu sumber protein hewani yang banyak dikonsumsi di Indonesia. Kualitas dan keamanan daging ayam untuk kesehatan manusia perlu dipertimbangkan. Daging ayam ini harus bebas dari residu antibiotik. Penelitian ini bertujuan untuk menentukan residu antibiotik dan kualitas daging serta hati ayam. Penelitian ini menggunakan total sampel 156 termasuk 52 daging dada, 52 paha dan 52 hati yang diperoleh dari 5 kelompok peternak ayam di 5 kecamatan di Kabupaten Pidie Jaya (Meureudu, Ulee Gle, Bandar Baru, Trienggadeng dan Meurah Dua). Rata-rata pH dari daging ayam yang diuji berkisar antara 5,8 dan 5,9. Nilai susut masak berkisar antara 33,28\% hingga 39,42\%. Residu antibiotik diuji dengan metode bioassay. Hasil penelitian menunjukkan bahwa residu antibiotik tidak terdeteksi pada daging dan hati kecuali residu penisilin yang ditemukan pada daging dada, paha dan hati ayam dari Kecamatan Trienggadeng.
\end{abstract}

Kata kunci: Metode biossay, daging ayam, hati ayam, Pidie Jaya.

\section{PENDAHULUAN}

Bahan pangan asal hewan dalam hal ini unggas baik ayam maupun itik merupakan salah satu komoditi pertanian khususnya sektor peternakan yang dibutuhkan untuk memenuhi kebutuhan akan zat gizi seperti protein, lemak, mineral, vitamin, dan komponen lainnya. Kebutuhan bahan pangan asal hewan ini semakin meningkat disebabkan oleh pertumbuhan penduduk, peningkatan pengetahuan, pergeseran gaya hidup dan tingkat kesehatan masyarakat semakin membaik. Kontribusi terbesar dalam penyediaan daging secara nasional umumnya berasal dari ternak unggas dan sapi potong.

Permintaan daging ayam setiap tahun semakin meningkat baik di dalam maupun luar Negeri. Daging ayam mulai digemari daripada daging lainnya karena kandungan lemaknya. Kandungan lemak daging ayam mencapai $14 \mathrm{~g}$, sedangkan kandungan lemak pada itik mencapai 28 g (Supriyadi 2009). Kendala yang dihadapi peternak ayam broiler adalah permintaan yang tinggi namun belum 
diimbangi dengan jumlah produksinya. Hal ini menjadikan peternak terpacu untuk meningkatkan produksi ayam. Salah satu cara dengan penambahan antibiotik ke dalam pakan yang berfungsi sebagai pemacu pertumbuhan.

Daging merupakan pangan asal hewani yang menjadi kebutuhan pokok bagi kehidupan manusia karena memiliki kandungan gizi dan sebagai sumber protein. Protein hewani sangat penting karena mengandung asam-asam amino yang mendekati susunan asam amino yang dibutuhkan manusia, serta lebih mudah dicerna dan lebih efisien pemanfaatannya. Daging ayam merupakan salah satu produk asal ternak yang memiliki angka konsumsi cukup tinggi, karena selain mudah diperoleh, pertumbuhannya cepat, dan harganya juga lebih terjangkau dibanding dengan jenis ternak besar (Saniwati et al. 2015).

Peternakan broiler umumnya rentan terhadap serangan penyakit yang disebabkan oleh virus, bakteri, parasit, jamur, lingkungan dan kekurangan salah satu unsur nutrisi (Tamalluddin 2012). Penggunaan antibiotik pada industri peternakan umumnya bertujuan untuk pengobatan ternak sehingga mengurangi resiko kematian dan mengembalikan kondisi ternak menjadi sehat. Pada industri peternakan, pemberian antibiotika juga digunakan sebagai imbuhan pakan (feed additive) untuk memacu pertumbuhan (growth promoter), meningkatkan produksi, dan meningkatkan efisiensi penggunaan pakan (Bahri et al. 2005).

Antibiotik masih diperbolehkan digunakan sebagian obat pada ternak namun harus sesuai dengan pengawasan. Karena banyaknya bahaya yang dapat terjadi akibat residu antibiotik pada produk asal hewani, maka penulis melakukan kajian dari beberapa jurnal yang telah membahas tentang kasus cemaran antibiotik pada produk unggas pada beberapa tahun terakhir. Adapun tujuan dari penulisan kajian ini adalah untuk mengetahui banyaknya kasus cemaran residu antibiotik pada ternak unggas di Indonesia serta meningkatkan kesadaran peternak dan konsumen akan bahaya dari cemaran antibiotika pada produk unggas

Kondisi kesehatan ternak dan optimalisasi produksi dapat dilakukan dengan melakukan kontrol terhadap penyakit yang dapat menyerang unggas. Antibiotik merupakan obat yang paling banyak digunakan di peternakan untuk tujuan tersebut. Selain digunakan untuk mengobati penyakit dan mencegah terjadinya penyakit, penggunaan antibiotik di peternakan juga bertujuan sebagai pemacu pertumbuhan (growth promotor). Penggunaan antibiotik sebagai pemacu pertumbuhan atau untuk pengobatan dan pencegahan penyakit yang tidak sesuai, dosis yang berlebihan, dan tidak memperhatikan masa henti obat (withdrawal time) dapat menimbulkan residu antibiotik pada otot dan produk hasil olahannya.

Menurut Bahri et al. (2010) hampir semua pabrik pakan menambahkan antibiotik ke dalam pakan komersial, sehingga sebagian besar pakan komersial yang beredar di Indonesia mengandung antibiotik. Penggunaan antibiotik yang kurang tepat ini dimungkinkan berkaitan dengan pola pemasaran obat hewan di lapangan, dimana 30.80\% peternak ayam pedaging skala kecil dan 33,30\% peternak ayam petelur skala kecil yang tidak mempunyai dokter hewan untuk mengawasinya, mendapat obat langsung dari distributor sehingga dikhawatirkan penggunaan obatobatan tersebut tidak mengikuti aturan yang benar. Selain itu peternak kurang memahami waktu henti suatu obat sehingga mengakibatkan munculnya residu pada produk ternak (Peter et al. 2002 ; Bahri et al. 2005).

Sesuai Surat Keputusan Menteri Pertanian Nomor 806/Kpts/TN.260/12/94 Tentang Klasifikasi Obat Hewan. Peraturan ini telah beberapa kali ditambah dan disempurnakan, jenis antibiotik yang direkomendasi sebagai bahan tambahan dalam pakan hewan yaitu avilamisina, avoparsina, basitrasin, enramisina, flavomisin (bambermisin), kitasamisin, kolistin sulfat, lasalosid, maduramisina, linkomisin $\mathrm{HCl}$, monensin natrium, narasina, salinomisin $(\mathrm{Na})$, spiramisin (embonat), virginiamisin.

Upaya lain yang dapat dilakukan untuk mendeteksi keberadaan residu antibiotik pada daging ayam broiler agar aman untuk dikonsumsi yaitu melalui pengujian secara rutin dengan monitoring atau surveilans residu antibiotik secara terkoordinasi. Hasil penelitian di Jabotabek yang dilakukan oleh Rusiana (2003), menyimpulkan bahwa dari 80 sampel ayam ras broiler, sebanyak 85\% daging dan $37 \%$ hati terancam residu antibiotik tylosin, penicillin, oxcytetracycline dan kanamycin. Selain itu, studi yang dilakukan di Kota Semarang dari 47 sampel yang diambil, yaitu 33 sampel dari pasar tradisional dan 14 sampel dari pasar modern, terbukti 3 sampel dari pasar tradisional positif mengandung residu Oksitetrasiklin, masing-masing 0.869 ppm (Pasar Johar), 0.271 (Pasar Sampangan) dan 0.366 (Pasar Dammar) yang melebihi Batas Maksimum Residu (BMR) yaitu lebih dari 0.1 ppm (Faizah 2011).

Berdasarkan hasil survey pendahuluan ke peternakan yang berada di bebarapa peternakan yang berasal di Kabupaten Pidie Jaya. memiliki beberapa usaha peternakan ayam broiler, peternakan ini memiliki 5000 ekor ayam broiler,dan memiliki 2 orang pekerja, peternakan ayam tersebut memberikan antibiotik yang dicampurkan pada air minum, antibiotik diberikan pada ayam untuk meningkatkan bobot ayam dengan cepat. Berdasarkan pernyataan tersebut maka penulis melakukan penelitian di Kabupaten Pidie Jaya.

\section{MATERI DAN METODE}

\section{Waktu dan Tempat Penelitian}

Penelitian ini telah dilakukan selama dua bulan mulai bulan Januari sampai Februari 2019. Penelitian dilakukan di 5 pasar di Kabupaten Pidie Jaya, analisa residu antibiotik dilakukan di Laboratorium Bagian Kesehatan Masyarakat Veteriner (Kesmavet) Balai Veteriner Medan. Provinsi Sumatera Utara.

\section{Materi Penelitian}

Penelitian ini menggunakan ayam broiler sebanyak 156 ekor yang diambil pada beberapa pasar di Kabupaten Pidie Jaya dilakukan di 5 pasar di Kabupaten Pidie Jaya Provinsi Aceh, Analisa di lakukan di Laboratorium Bagian Kesehatan Masyarakat Veteriner (Kesmavet) Balai Veteriner Medan. Provinsi Sumatera Utara. 


\section{Prosedur Penelitian}

Dalam penelitian ini digunakan metode study observation dengan desain cross sectional yaitu variabel penelitian yang merupakan akibat dari paparan terhadap hazard (bahaya) di ukur dalam satu waktu tertentu, pengukuran sesaat dan hanya satu kali. Pada tahap awal penelitian dilakukan survey terhadap pedagang yang ada di Kabupaten Pidie Jaya meliputi jumlah pasar dan lokasi. Sampel yang di ambil adalah daging bagian dada, hati dan bagian paha dari pasar di wilayah Kabupaten Pidie Jaya yang tersebar di lima kecamatan, dimana besaran sampel dihitung menggunakan software WinEpiscope 2.0 dengan menggunakan asumsi tingkat kepercayaan 95\%, prevalensi dugaan 50\%, dan tingkat kesalahan 5\%, sehingga diperoleh besaran sampel sebanyak 52. Tiap kelompok dihitung besaran sampelnya menurut alokasi proporsional (proportional allocation) dari total populasi peternakan ayam broiler. Besaran sampel setiap peternakan ayam broiler di Kabupaten Pidie Jaya dapat dilihat pada Tabel 1.

Tabel 1. Besaran sampel setiap peternakan ayam broiler di Kabupaten Pidie Jaya (Disnakkan Pemkab Pidie Jaya)

\begin{tabular}{lllcc}
\hline No & Kecamatan & \multicolumn{1}{c}{ Pasar } & $\begin{array}{c}\text { Jumlah } \\
\text { peternakan }\end{array}$ & $\begin{array}{c}\text { Besaran } \\
\text { sampel }\end{array}$ \\
\hline 1 & Meureudu & Kota & 15 & 8 \\
& & Meureudu & & \\
& & Rhieng & 15 & 8 \\
2 & \multirow{2}{*}{ Ulee Gle } & Ulee & 10 & 5 \\
& & gle dalam & & \\
3 & Bandar baru & Lueng Putu & 11 & 7 \\
4 & Trienggadeng & Trienggadeng & 20 & 10 \\
& & Pangwa & 12 & 6 \\
5 & Meurah dua & Kuta simpang & 15 & 8 \\
\hline Jumlah & & 98 & 52 \\
\hline
\end{tabular}

\section{Uji Tapis (Screening Test) Residu Antibiotik}

Metode uji tapis residu antibiotik pada daging dada, paha, dan hati ayam broiler mengacu pada Standard Nasional Indonesia (SNI) 7424 tahun 2008 tentang Metode Uji Tapis (Screening Test) Residu Antibiotik pada Daging, Telur, dan Susu secara Biossay. Pada pengujian ini residu antibiotik dalam sampel akan menghambat pertumbuhan mikroorganisme pada media agar. Penghambatan dapat dilihat dengan terbentuknya daerah hambatan di sekitar kertas cakram. Besarnya diameter daerah zona hambatan menunjukkan konsentrasi residu antibiotik.

Pada metode ini dilakukan pengujian terhadap4 golongan antibiotik yaitu golongan penisilin, tetrasiklin, aminoglikosida, makrolida. Mikroba yang di gunakan pada pengujian ini adalah spora bakteri Bacillus stearothermophilus ATCC 7953 untuk pengujian antibiotik golongan penisilin, spora bakteri Bacillus cereus ATCC 11778 untuk pengujian antibiotik golongan tetrasiklin, spora bakteri Bacillus subtilis ATCC 6633 untuk pengujian antibiotik golongan aminoglikosida dan vegetatif Kocuria rizhophila (Micrococcus Luteus) ATCC 9341 untuk pengujian antibiotik golongan makrolida.
Pelaksanaan pengujian dengan uji tapis terdiri dari beberapa tahap, yaitu:

\section{Pembuatan Larutan Dapar/Bahan Kimia}

Larutan dapar fosfat nomor 1 dibuat dengan menimbang $7 \mathrm{~g} \mathrm{KH}_{2} \mathrm{PO}_{4}$ dan $6 \mathrm{~g} \mathrm{Na} 2 \mathrm{HPO} 4$ yang dilarutkan dalam aquabides sampai $1.000 \mathrm{~mL}$, dengan mengatur $\mathrm{pH}$ hingga menjadi $6.0 \pm 0.1$, lalu di sterilisasi menggunakan autoklaf pada suhu $121 \pm 1^{\circ} \mathrm{C}$, selama 15 menit.

Larutan dapar fosfat nomor 2 dibuat dengan menimbang 6.4 gram $\mathrm{KH}_{2} \mathrm{PO}_{4}$ dan $18.9 \mathrm{~g} \mathrm{Na}_{2} \mathrm{HPO}_{4}$ yang dilarutkan dalam aquabides sampai $1.000 \mathrm{~mL}$, dengan mengatur $\mathrm{pH}$ hingga menjadi $7.0 \pm 0.1$, kemudian disterilisasi dengan autoklaf pada suhu $121 \pm 1{ }^{\circ} \mathrm{C}$ dengan tekanan Psi atau $1.03421 \times 105$ pascal selama 15 menit.

Larutan dapar fosfat nomor 3 dibuat dengan menimbang 3.5 g KH2 PO4 dan 3 g Na2 HPO4 yang dilarutkan dalam aquabides sampai $1.000 \mathrm{~mL}$, dengan mengatur $\mathrm{pH}$ hingga menjadi $6.0 \pm 0.1$ kemudian di sterilisasi dengan autoklaf pada suhu $121 \pm 1{ }^{\circ} \mathrm{C}$, dengan tekanan $15 \mathrm{psi}$ atau $1.03421 \times 105$ pascal selama 15 menit.

\section{Pembuatan Media}

Pembuatan mediabiakan Bacillus stearothermophilus untuk pengujian antibiotik golongan penisilin dilakukan dengan menimbang peptone $5.0 \mathrm{~g}$, yeast extract $12 \mathrm{~g}$, bacto agar $15 \mathrm{~g}$, dextrose $1 \mathrm{~g}$ dan akuabides $1.000 \mathrm{~mL}$. Peptone, dextrose, dan yeast extract dilarutkan dalam sebagian akuabides, setelah tercampur rata ditambahkan bacto agar dan ditambahkan akuabides hingga volume keseluruhan menjadi $1.000 \mathrm{~mL}$. Derajat keasaman disesuaikan pada $\mathrm{pH}$ $5.7 \pm 0.1$ dan dididihkan sampai bacto agar terlarut.

Media biakan Bacillus subtilis untuk pengujian antibiotik golongan aminoglikosida dibuat dengan menimbang peptone $5 \mathrm{~g}$, beef extract $3 \mathrm{~g}$, bacto agar $15 \mathrm{~g}$ dan akuabides $1.000 \mathrm{~mL}$. Peptone dan beef extract dilarutkan dalam sebagian akuabides kemudian ditambahkan bacto agar, selanjutnya ditambahkan akuabides hingga volume keseluruhan menjadi $1.000 \mathrm{~mL}$. Derajat keasaman disesuaikan pada $\mathrm{pH} 8.5 \pm 0.1$ dan dididihkan sampai bacto agar terlarut.

Media biakan Bacillus cereus untuk pengujian antibiotik golongan tetrasiklin dibuat dengan menimbang peptone $6 \mathrm{~g}$, beef extract $1.5 \mathrm{~g}$, yeast extract $3 \mathrm{~g}, \mathrm{KH}_{2} \mathrm{PO}_{4}$ $1.35 \mathrm{~g}$, bacto agar $15 \mathrm{~g}$ dan akuabides $1.000 \mathrm{~mL}$. Peptone, beef extract, yeast extract dan $\mathrm{KH}_{2} \mathrm{PO}_{4}$ dilarutkan dalam sebagian akuabides, kemudian ditambahkan bacto agar, selanjutnya ditambahkan akuabides hingga volume menjadi $1.000 \mathrm{~mL}$. Derajat keasaman disesuaikan pada $\mathrm{pH} 5.7 \pm 0.1$ dan dididihkan sampai bacto agar terlarut.

Media biakan Micrococcus luteus (Kocuria rizophila) untuk pengujian antibiotikgolongan makrolida dibuat dengan menimbang peptone $6 \mathrm{~g}$, beef extract $1.5 \mathrm{~g}$, yeast extract 3 $\mathrm{g}$, glucose $1 \mathrm{~g}$, bacto agar $15 \mathrm{~g}$, dan akuabides $1.000 \mathrm{~mL}$. Peptone, beef extract, yeast extract dan glucose dilarutkan dalam sebagian akuabides, kemudian ditambahkan bacto agar, selanjutnya ditambahkan akuabides hingga volume menjadi $1.000 \mathrm{~mL}$. Derajat keasaman disesuaikan pada $\mathrm{pH}$ $8.5 \pm 0.1$ dan dididihkan sampai bacto agar terlarut. 


\section{Pembuatan Larutan Stok Baku Pembanding}

Sebelum melakukan penimbangan, perlu diperhitungkan potensi dari masing-masing standar yang tertera pada label. Pembuatan larutan baku pembanding penisilin dilakukan dengan menimbang sejumlah baku penisilin $\mathrm{G}$ kemudian dilarutkan dalam dapar nomor 1 hingga didapatkan konsentrasi $1.000 \mathrm{IU} / \mathrm{mL}$. Larutan baku pembanding oksitetrasiklin dibuat dengan menimbang sejumlah baku pembanding oksitetrasiklin hidroklorida kemudian dilarutkan dalam akuabides hingga diperoleh konsentrasi $1.000 \mu \mathrm{g} / \mathrm{mL}$. Pembuatan larutan baku pembanding kanamisin dilakukan dengan menimbang sejumlah baku pembanding kanamisin sulfat kemudian dilarutkan dalam dapar nomor 3 hingga diperoleh konsentrasi $1.000 \mu \mathrm{g} / \mathrm{mL}$. Larutan baku pembanding tilosin dibuat dengan menimbang sejumlah baku pembanding tilosin tartrat dilarutkan $10 \%$ methanol dalam akuabides hingga diperoleh konsentrasi $1.000 \mu \mathrm{g} / \mathrm{mL}$.

\section{Peubah yang Diamati}

Peubah yang diamati dalam penelitian ini meliputi residu antibiotik, susut masak, dan $\mathrm{pH}$ daging.

\section{Susut Masak}

Cara melakukan uji susut masak sampel daging ditimbang kemudian dimasukkan kedalam plastik polietilen dan ditutup rapat pada saat perebusan air tidak dapat masuk ke dalam kantong plastik, kemudian sampel direbus dalam Waterbath pada suhu $80^{\circ} \mathrm{C}$ selama satu jam. Sampel daging di dinginkan dengan memasukan ke dalam Beakerglass yang berisi air dingin dengan temperatur $10{ }^{\circ} \mathrm{C}$ selama 15 menit, kemudian sampel dikeluarkan dari kantong plastik dan dikeringkan dengan kertas saring dan dilakukan penimbangan kembali. Menurut Soeparno, 1992) susut masak dihitung menggunakan rumus:

$$
\text { SM }(\text { Susut masak })(\%)=\frac{\text { Berat sebelum dimasak }(g)-\text { berat setelah dimasak }(g)}{\text { berat sebelum } \operatorname{dimasak}(g)} \times 100 \%
$$

\section{pH Daging}

Pengukuran $\mathrm{pH}$ menggunakan metode Ockerman (1983) dengan cara sebelum melakukan pengukuran, $\mathrm{pH}$ meter di kalibrasi dengan larutan buffer $\mathrm{pH} 4$ dan 7, demikian pula elektroda dibilas dengan aquades dan dikeringkan. Sampel daging di timbang seberat $5 \mathrm{~g}$ dan dicampur dengan $25 \mathrm{~mL}$ aquades, kemudian di haluskan. Elektroda dicelupkan ke dalam sampel dan nilai $\mathrm{pH}$ dapat dibaca pada skala yang ditunjukkan oleh angka penunjuk.

\section{Analisis Data}

Analisis data yang dilakukan adalah analisis deskriptif dengan menyajikan hasil uji dalam bentuk tabel (Mattjik dan Sumertajaya 2002). Analisis data tersebut dilakukan dengan menggunakan program Microsoft Excel 2007.

\section{HASIL DAN PEMBAHASAN}

\section{Hasil Pengujian Residu Antibiotik dengan Biossay}

Biossay merupakan suatu metode pengujian yang menggunakan mikroorganisme untuk mendeteksi senyawa antibiotik yang masih aktif. Metode pengujian ini yang juga dikenal dengan"four plate method" merupakan metode deteksi residu antibiotik yang banyak digunakan saat ini. Metode ini digunakan juga di laboratorium di Eropa untuk pengawasan bahan pangan asal hewan. Metode ini juga memiliki beberapa variasi, dengan perbedaan pada jumlah dan jenis strain bakteri yang digunakan akan mempengaruhi jumlah cawan yang digunakan, periode inkubasi, $\mathrm{pH}$ media dan jumlah media yang digunakan untuk pertumbuhan bakteri yang optimal, dan perbedaan tingkat deteksi (BSN 2008; Kirbiš 2010).

Berdasarkan hasil penelitian pada Tabel 2 bahwa residu antibiotik pada daging dan hati ayam broiler di Kabupaten Pidie Jaya tidak di temukan residu antibiotik, hal tersebut di tujukan dengan hasil yang negatif, ditemukannya residu antibiotik golongan penisilin pada salah satu peternakan yang ada di Kabupaten Pidie Jaya hal tersebut dapat disebabkan oleh pemberian antibiotik pada ayam selama masa pemeliharaan dengan tujuan pengobatan penyakit dan dipotong sebelum withdrawal time (masa henti obat) berakhir sehingga antibiotik masih terakumulasi di daging ayam. Penyebab lain yang dapat menimbulkan hasil uji positif adalah pakan komersial yang diberikan sewaktu masa pemeliharaan mengandung antibiotik, menurut (Bahri et al. 2008) hampir semua pabrik pakan menambahkan senyawa obat berupa antibiotik sebagai aditif pakan. Namun demikian, Pemerintah melalui UU No. 18 Tahun 2009 tentang Peternakan dan kesehatan hewan mulai melarang penggunaan antibiotik sebagai imbuhan pakan yang tertuang dalam pasal 22 ayat (4c).

Regulasi tersebut menjadi acuan dasar dan hukum bagi pemerintah dalam membatasi penggunaan antibiotik sebagai imbuhan pakan sehingga memberikan dampak positif bagi penurunan residu antibiotik pada produk pangan asal hewan khusus daging ayam. Larangan penggunaan antibiotik Growth promoter (AGP) pada sektor peternakan akan mulai efektif pada tahun awal Januari 2018. Hal ini pun sudah tertuang pada Permentan No 14/2017 tentang klasifikasi obat hewan. Adanya aturan ini mengharuskan produsen obat hewan untuk mencari peluang dalam menghasilkan produk-produk pengganti antibiotik yang selama ini digunakan untuk menjaga ketahanan ternak, solusi nya adalah dengan melakukan biosecurity yang lebih ketat tetapi produsen juga harus menggunakan produkproduk yang lebih natural seperti enzim, probiotik, herbal dan lainya.

Larangan penggunaan antibiotik yang berlebihan memang sudah dicanangkan secara global. Larangan ini bukan hanya diperuntukkan bagi sektor peternakan seperti unggas namun juga pada manusia. Karena itu, pihak produsen obat hewan harus mendukung upaya pemerintah Indonesia. Nantinya antibiotik pada unggas ini masih dapat digunakan, tetapi hanya digunakan sebagai pengobatan dan maksimum penggunaannya selama tujuh hari. Karena itulah, pengalihan antibiotik dari feed additive (makanan tambahan) menjadi pengobatan penting dilakukan. Karena peraturan ini sudah dicanangkan cukup lama, perusahaanperusahaan produsen pakan ternak sudah banyak yang mengetahui tentang penggunaan antibiotik ini, sehingga 
Masrianto et al.

Jurnal Ilmu Produksi dan Teknologi Hasil Peternakan 7 (3): 102-110

Tabel 2. Hasil pemeriksaan residu antibiotik pada sampel daging ayam broiler

\begin{tabular}{|c|c|c|c|c|c|c|c|c|c|}
\hline \multirow[t]{2}{*}{ Kecamatan } & \multirow[t]{2}{*}{ Pasar } & \multirow[t]{2}{*}{$\begin{array}{c}\text { Jenis } \\
\text { Sampel }\end{array}$} & \multirow[t]{2}{*}{ (n) } & \multirow{2}{*}{$\begin{array}{c}\text { Waktu dan } \\
\text { Tanggal } \\
\text { Pengambilan }\end{array}$} & \multirow[t]{2}{*}{$\begin{array}{c}\text { Asal } \\
\text { Peternakan }\end{array}$} & \multicolumn{4}{|c|}{$\begin{array}{l}\text { Positif terdapat residu antibiotik berdasarkan } \\
\text { golongan }\end{array}$} \\
\hline & & & & & & $\begin{array}{l}\text { Aminog- } \\
\text { likosida }\end{array}$ & Makrolida & Penisilin & Tetrasiklin \\
\hline \multirow[t]{6}{*}{ Meureudu } & \multirow[t]{3}{*}{$\begin{array}{c}\text { Kota } \\
\text { Meureudu }\end{array}$} & $\begin{array}{c}\text { Daging } \\
\text { dada }\end{array}$ & 8 & $\begin{array}{l}13 \text { Februari } \\
2019 \text { jam }\end{array}$ & \multirow{3}{*}{$\begin{array}{c}\text { Pidie Jaya } \\
\text { Aceh } \\
\text { Besar }\end{array}$} & - & - & - & - \\
\hline & & $\begin{array}{c}\text { Daging } \\
\text { paha }\end{array}$ & 8 & 06:30 WIB & & - & - & - & - \\
\hline & & $\begin{array}{l}\text { Daging } \\
\text { hati }\end{array}$ & 8 & & & - & - & - & - \\
\hline & \multirow[t]{3}{*}{ Rhieng } & $\begin{array}{c}\text { Daging } \\
\text { dada }\end{array}$ & 8 & 13-Feb-19 & \multirow{3}{*}{$\begin{array}{c}\text { Pidie Jaya } \\
\text { Aceh } \\
\text { Besar }\end{array}$} & - & - & - & - \\
\hline & & $\begin{array}{c}\text { Daging } \\
\text { paha }\end{array}$ & 8 & $\begin{array}{c}\text { Jam 06:40 } \\
\text { WIB }\end{array}$ & & - & - & - & - \\
\hline & & $\begin{array}{c}\text { Daging } \\
\text { hati }\end{array}$ & 8 & & & - & - & - & - \\
\hline \multirow[t]{3}{*}{ Ulee Gle } & \multirow[t]{3}{*}{$\begin{array}{l}\text { Ulee Gle } \\
\text { Dalam }\end{array}$} & $\begin{array}{c}\text { Daging } \\
\text { dada }\end{array}$ & 5 & 13-Feb-19 & \multirow{3}{*}{$\begin{array}{c}\text { Pidie Jaya } \\
\text { Aceh } \\
\text { Besar }\end{array}$} & - & - & - & - \\
\hline & & $\begin{array}{c}\text { Daging } \\
\text { paha }\end{array}$ & 5 & $\begin{array}{c}\text { Jam 08:00 } \\
\text { WIB }\end{array}$ & & - & - & - & - \\
\hline & & $\begin{array}{l}\text { Daging } \\
\text { hati }\end{array}$ & 5 & & & - & - & - & - \\
\hline \multirow[t]{3}{*}{$\begin{array}{c}\text { Bandar } \\
\text { Baru }\end{array}$} & \multirow[t]{3}{*}{$\begin{array}{c}\text { Leung } \\
\text { Putu }\end{array}$} & $\begin{array}{l}\text { Daging } \\
\text { dada }\end{array}$ & 7 & 13-Feb-19 & \multirow{3}{*}{$\begin{array}{c}\text { Pidie Jaya } \\
\text { Aceh } \\
\text { Besar }\end{array}$} & - & - & - & - \\
\hline & & $\begin{array}{c}\text { Daging } \\
\text { paha }\end{array}$ & 7 & $\begin{array}{c}\text { Jam 08:30 } \\
\text { WIB }\end{array}$ & & - & - & - & - \\
\hline & & $\begin{array}{c}\text { Daging } \\
\text { hati }\end{array}$ & 7 & & & - & - & - & - \\
\hline \multirow[t]{6}{*}{$\begin{array}{l}\text { Triengga- } \\
\text { deng }\end{array}$} & \multirow[t]{3}{*}{$\begin{array}{l}\text { Triengga- } \\
\text { deng }\end{array}$} & $\begin{array}{c}\text { Daging } \\
\text { dada }\end{array}$ & 10 & 13-Feb-19 & \multirow{3}{*}{$\begin{array}{c}\text { Pidie Jaya } \\
\text { Aceh } \\
\text { Besar }\end{array}$} & - & - & + & - \\
\hline & & $\begin{array}{c}\text { Daging } \\
\text { paha }\end{array}$ & 10 & $\begin{array}{c}\text { Jam 09:00 } \\
\text { WIB }\end{array}$ & & - & - & + & - \\
\hline & & $\begin{array}{l}\text { Daging } \\
\text { hati }\end{array}$ & 10 & & & - & - & + & - \\
\hline & \multirow[t]{3}{*}{ Pangwa } & $\begin{array}{c}\text { Daging } \\
\text { dada }\end{array}$ & 6 & 13-Feb-19 & \multirow{3}{*}{$\begin{array}{c}\text { Pidie Jaya } \\
\text { Aceh } \\
\text { Besar }\end{array}$} & - & - & - & - \\
\hline & & $\begin{array}{c}\text { Daging } \\
\text { paha }\end{array}$ & 6 & $\begin{array}{c}\text { Jam 09:20 } \\
\text { WIB }\end{array}$ & & - & - & - & - \\
\hline & & $\begin{array}{l}\text { Daging } \\
\text { hati }\end{array}$ & 6 & & & - & - & - & - \\
\hline \multirow[t]{3}{*}{$\begin{array}{l}\text { Meurah } \\
\text { Dua }\end{array}$} & \multirow[t]{3}{*}{$\begin{array}{c}\text { Kuta } \\
\text { Simpang }\end{array}$} & $\begin{array}{l}\text { Daging } \\
\text { dada }\end{array}$ & 8 & 13-Feb-19 & \multirow{3}{*}{$\begin{array}{c}\text { Pidie Jaya } \\
\text { Aceh } \\
\text { Besar }\end{array}$} & - & - & - & - \\
\hline & & $\begin{array}{c}\text { Daging } \\
\text { paha }\end{array}$ & 8 & $\begin{array}{c}\text { Jam 10:00 } \\
\text { WIB }\end{array}$ & & - & - & - & - \\
\hline & & $\begin{array}{c}\text { Daging } \\
\text { hati }\end{array}$ & 8 & & & - & - & - & - \\
\hline
\end{tabular}

Keterangan : (-) Tidak ditemukan residu antibiotik (+) : Ditemukan residu antibiotik

mereka lebih siap menjalankan aturan yang ada. Masih ada peternak yang mencampur sendiri antibiotik kepada pakan ternaknya. Saya rasa mereka yang belum siap terhadap aturan ini.

Penggunaan antibiotik pada ternak dapat mengakibatkan residu pada produk ternak yang dihasilkan seperti daging, susu, dan telur yang dikonsumsi manusia.
Antibiotik yang digunakan sebagai terapi akibat penyakit yang disebabkan infeksi bakteri harus memperhatikan dosis dan waktu henti obat pada saat ternak dipotong. Penggunaan antibiotik sebagai pemacu pertumbuhan akan menghasilkan akumulasi residu dalam produk hewan yang berakibat buruk pada kesehatan manusia karena bersifat racun, mengakibatkan perubahan mikroflora normal pada 
saluran pencernaan dan mengakibatkan resistensi bakteri terhadap antibiotik (Nisha 2011).

Berdasarkan hasil pengamatan tidak ditemukanya residu antibiotik pada daging ayam broiler dikarenakan sebagian peternak sudah mengerti tentang penggunaan antibiotik dalam pakan ternak. Ditemukanya residu antibiotik golongan penisilin pada salah satu peternakan yang ada di Kabupaten Pidie Jaya hal tersebut dapat disebabkan oleh pemberian antibiotik pada ayam selama masa pemeliharaan dengan tujuan pengobatan penyakit dan dipotong sebelum Withdrawal time (masa henti obat) berakhir sehinggg antibiotik masih terakumulasi di dalam daging ayam. Penyebab lain yang dapat menimbulkan hasil uji positif residu antibiotik adalah pakan komersial yang diberikan semasa waktu pemeliharaan mengandung antibiotik. Ternak yang diberi pakan bercampur Antibiotic Growth Promoters (AGP), ternyata berdampak buruk bagi kesehatan manusia.

Residu antibiotik pada jaringan otot ayam atau telur, membuat manusia mengalami resistensi (kebal) pada beberapa jenis antibiotik. Jika manusia mengkonsumsi daging atau telur ayam yang diberi pakan AGP, maka dampaknya akan mengalami resistensi pada beberapa jenis antibiotik Antibiotik pada AGP itu untuk membunuh bakteri patogen pada pencernaan ayam. Seperti Salmonella, Campylobacter, Enterococci, dan Escherichia coli. Dengan mengetahui efek negatif dari residu antibiotik terhadap kesehatan, maka dibuat ketentuan nilai Batas Maksimum Residu antibiotik (BMR) dalam produk ternak (daging, susu, telur) untuk masing-masing antibiotik berdasarkan Standar Nasional Indonesia (SNI) 01-6366-2000. Dengan mengetahui BMR setiap golongan antibiotik dari suatu bahan pangan hasil ternak, batas keamanan produk dapat ditentukan jika dikonsumsi oleh manusia. BMR (Batas Maksimum Residu) golongan tetrasiklin pada produk ternak yaitu sebesar 0.1 ppm, namun batas cemaran residu antibiotik untuk hati tidak dicantumkan. Pemberian antibiotik baik sebagai pengobatan maupun sebagai pemacu pertumbuhan diberikan dalam pengawasan dokter hewan. Jika harus dihilangkan residu antibiotik salah satu nya dengan cara mematuhi aturan pakai setiap jenis antibiotik.

Salah satu upaya menghilangkan atau mengurangi residu antibiotik pada produk peternakan, perhatian terhadap waktu henti pemberian (withdrawal time) antibiotik yaitu jarak antara pemberian terakhir sampai dengan produk ternak tersebut dapat dikonsumsi.

\section{Susut Masak}

Susut masak merupakan persentase berat daging yang hilang akibat pemasakan dan merupakan fungsi dari waktu dan suhu pemasakan. Daging dengan susut masak yang rendah mempunyai kualitas yang relatif lebih baik dari pada daging dengan persentase susut masak yang tinggi, hal ini karena kehilangan nutrisi selama proses pemasakan akan lebih sedikit.

Hasil penelitian pada Tabel 3 menunjukkan bahwa susut masak daging ayam broiler dari yang tertinggi berturut-turut sebesar 39.42, 37.66, 36.76, 35.82, 34.05, 33.28. Lawrie (2009) menyatakan bahwa susut masak daging ayam broiler pada umumnya bervariasi antara 1.5 sampai 54.5\% dengan kisaran 15\% sampai 40\%.

Susut masak dipengaruhi oleh temperatur dan lama pemasakan, semakin tinggi temperatur pemasakan maka semakin besar kadar cairan daging yang hilang sampai mencapai tingkat yang konstan. Susut masak dipengaruhi oleh $\mathrm{pH}$, panjang sarkomer serabut otot, panjang potongan serabut otot, status kontraksi miofibril, ukuran dan berat sampel daging serta penampang lintang daging (Soeparno et al. 2011).

Menurut Soeparno (2015) daging didefinisikan sebagai semua jaringan hewan dan semua produk hasil pengolahan jaringan-jaringana tersebut yang sesuai untuk dimakan serta tidak menimbulkan gangguan kesehatan bagi yang memakannya. Kualitas fisik daging antara lain $\mathrm{pH}$, daya ikat air (DIA), susut masak dan keempukan. Kualitas fisik daging dipengaruhi oleh proses sebelum dan setelah pemotongan.Faktor sebelum pemotongan yang dapat mempengaruhi kualitas daging adalah genetik, spesies, bangsa, tipe ternak, jenis kelamin, umur, pakan, termasuk bahan aditif (hormon, antibiotik, dan mineral) dan keadaan stress. Faktor setelah pemotongan yang mempengaruhi kualitas daging antar lain meliputi $\mathrm{pH}$ daging dan metode penyimpanan (Soeparno 2015)

$\mathrm{pH}$ adalah nilai keasamaan suatu senyawa atau nilai hidrogen dari senyawa tersebut, kebalikan dari nilai $\mathrm{pH}$ yaitu nilai kebasaan. Jaringan otot hewan saat masih hidup mempunyai nilai $\mathrm{pH}$ sekitar 5.1-7.2 dan menurun setelah pemotongan mengalami glikolisis dan dihasilkan asam laktat yang akan mempengaruhi $\mathrm{pH}, \mathrm{pH}$ ultimat normal daging postmortem adalah sekitar 5.4-5.8. Jaringan otot hewan saat masih hidup mempunyai nilai $\mathrm{pH}$ sekitar 5.1-7.2 dan menurun setelah pemotongan mengalami glikolsis dan dihasilkan asam laktat yang akan mempengaruhi $\mathrm{pH}, \mathrm{pH}$ ultimat normal daging postmortem adalah sekitar 5.4-5.8.

Stres sebelum pemotongan, pemberian injeksi hormon dan obat-obatan (kimiawi) tertentu, spesies, individu ternak, macam otot, stimulasi listrik dan aktivitas enzim yang mempengaruhi glikolisis adalah faktor-faktor yang dapat menghasilkan variasi $\mathrm{pH}$ daging. Misalnya, stres sebelum pemotongan, injeksi adrenalin atau insulin (Bouton et al. 1957 dalam Soeparno 2015). Menurut Soeparno (2015), spesies, tipe otot, glikogen otot dan variabilitas diantara ternak dapat mempengaruhi nilai $\mathrm{pH}$, faktor ekstrinsik yang mempengaruhi $\mathrm{pH}$ adalah pakan, temperatur lingkungan, perlakuan bahan aditif sebelum pemotongan dan stres sebelum pemotongan.

\section{Nilai pH}

Nilai $\mathrm{pH}$ merupakan indikator penting dalam menilai kualitas fisik daging. Nilai $\mathrm{pH}$ juga dapat mempengaruhi keempukan, susut masak dan daya mengikat air. Hasil penilaian kualiatas daging ayam broiler pada penelitian ini dapat dilihat pada Tabel 3. Nilai $\mathrm{pH}$ daging ayam broiler dari ke lima pasar menunjukkan perbedaan, kisaran $\mathrm{pH}$ daging dari ke 5 pasar tersebut adalah 5.8-5.9.

Nilai $\mathrm{pH}$ ini relatif standar dari kisaran nilai $\mathrm{pH}$ daging menurut pendapat Van Laack et al. (2010) yaitu 5.96-6.07 dan hasil penelitian Prayitno dan Suryanto (2012) 
Masrianto et al.

Jurnal Ilmu Produksi dan Teknologi Hasil Peternakan 7 (3): 102-110

Tabel 3. Hasil pemeriksaan susut masak dan $\mathrm{pH}$ daging ayam broiler

\begin{tabular}{|c|c|c|c|c|c|c|c|}
\hline Kecamatan & Jenis sampel & $\begin{array}{c}\text { Susut masak } \\
(\%)\end{array}$ & $\mathrm{pH}$ daging & Kecamatan & Jenis sampel & $\begin{array}{c}\text { Susut masak } \\
(\%)\end{array}$ & $\mathrm{pH}$ daging \\
\hline \multirow[t]{11}{*}{ Meureudu } & \multirow[t]{11}{*}{ Daging ayam } & 30.02 & 6.10 & \multirow[t]{11}{*}{ Trienggadeng } & \multirow[t]{11}{*}{ Daging ayam } & 30.05 & 6.00 \\
\hline & & 30.17 & 5.70 & & & 30.20 & 5.70 \\
\hline & & 35.87 & 5.70 & & & 34.18 & 5.80 \\
\hline & & 32.15 & 5.90 & & & 32.20 & 5.90 \\
\hline & & 32.21 & 5.80 & & & 37.24 & 5.80 \\
\hline & & 34.29 & 5.80 & & & 35.28 & 5.80 \\
\hline & & 33.28 & 5.70 & & & 34.26 & 5.70 \\
\hline & & 37.22 & 5.80 & & & 38.65 & 5.80 \\
\hline & & 35.27 & 5.70 & & & 34.05 & 5.70 \\
\hline & & 34.40 & 5.90 & & & 39.40 & 5.90 \\
\hline & & $33.49 \pm 2.39$ & $5.81 \pm 0.13$ & & & $34.55 \pm 3.22$ & $5.81 \pm 0.10$ \\
\hline \multirow[t]{11}{*}{ Ulee Glee } & \multirow[t]{11}{*}{ Daging ayam } & 36.80 & 5.80 & \multirow[t]{22}{*}{ Meurah Dua } & \multirow[t]{22}{*}{ Daging ayam } & 36.14 & 5.70 \\
\hline & & 37.59 & 5.90 & & & 30.17 & 5.90 \\
\hline & & 38.68 & 5.90 & & & 35.33 & 5.90 \\
\hline & & 37.28 & 5.80 & & & 34.73 & 5.80 \\
\hline & & 34.05 & 5.80 & & & 20.15 & 5.80 \\
\hline & & 35.33 & 5.90 & & & 37.50 & 5.90 \\
\hline & & 36.14 & 6.00 & & & 34.70 & 6.00 \\
\hline & & 36.28 & 5.90 & & & 39.50 & 5.90 \\
\hline & & 33.69 & 5.80 & & & 38.60 & 5.80 \\
\hline & & 37.51 & 5.70 & & & 33.70 & 5.70 \\
\hline & & $36.34 \pm 1.59$ & $5.85 \pm 0.08$ & & & $34.05 \pm 5.55$ & $5.84 \pm 0.10$ \\
\hline \multirow[t]{11}{*}{ Bandar Baru } & \multirow[t]{11}{*}{ Daging ayam } & 35.82 & 5.80 & & & & \\
\hline & & 36.17 & 5.90 & & & & \\
\hline & & 37.65 & 5.80 & & & & \\
\hline & & 34.62 & 5.90 & & & & \\
\hline & & 36.76 & 5.90 & & & & \\
\hline & & 20.19 & 5.70 & & & & \\
\hline & & 39.42 & 5.80 & & & & \\
\hline & & 34.73 & 5.70 & & & & \\
\hline & & 34.71 & 5.80 & & & & \\
\hline & & 37.60 & 5.90 & & & & \\
\hline & & $34.77 \pm 5.35$ & $5.82 \pm 0.08$ & & & & \\
\hline
\end{tabular}

dimana $\mathrm{pH}$ daging ayam broiler tanpa perlakuan apapun adalah 6.11-6.25, tetapi hasil penelitian ini masih lebih rendah dari hasil penelitian Afrianti et al. (2013) dimana daging ayam broiler tanpa perlakuan apapun memiliki $\mathrm{pH}$ rata-rata 6.79 dalam rentang masa simpan 6-12 jam.

Hasil penelitian Duna et al. (2010) pada otot dada broiler memperlihatkan bahwa setelah enam jam postmortem dicapai $\mathrm{pH}$ 5.94. Perubahan $\mathrm{pH}$ daging setelah pemotongan ternak dipengaruhi oleh ketersediaan asam laktat di dalam otot, ketersediaan asam laktat ini dipengaruhi oleh kandungan glikogen, dan kandungan glikogen dipengaruhi oleh penangan ternak sebelum dipotong.

Kandungan glikogen otot sangat rendah, yaitu pada kisaran 0.5 sampai $1.3 \%$ dari berat daging segar, sehingga penurunan $\mathrm{pH}$ daging terjadi secara bertahap dan membutuhkan jangka waktu yang lama.

Berdasarkan lama waktu setelah proses pemotongan, $\mathrm{pH}$ daging ayam mengalami penurunan. Hasil penelitian Suradi (2009) menujukan bahwa daging ayam broiler memiliki $\mathrm{pH} 6.31$ pada saat segera setelah pemotongan, kemudian mengalami penurunan dengan semakin lamanya jangka waktu setelah pemotongan, yaitu 2, 4, 6, 8, 10, dan 12 jam dengan $\mathrm{pH}$ masing-masing $6.24 ; 6.16 ; 6.10 ; 6.02$; 5.96 dan 5.82 .

Bilamerujukpadahasil-hasil penelitian tersebut diatas maka daging ayam broiler dari ke lima pasar memiliki kisaran pH yang masih wajar sebagai daging konsumsi. Seyogianya daging ayam yang telah lebih dari 10 jam akan memiliki pH di bawah 6. Perbedaan jenis kelamin tidak berpengaruh terhadap nilai $\mathrm{pH}$. Nilai $\mathrm{pH}$ daging pada ayam broiler jantan 
dan ayam broiler betina sama. Nilai $\mathrm{pH}$ daging yang tidak berbeda nyata disebabkan karena kandungan glikogen otot yang sama dan dapat menyebabkan kandungan asam laktat pada daging postmortem sama. Standar Nasional Indonesia menyatakan nilai $\mathrm{pH}$ produk pangan yaitu 6-7 (Afrianti et al. 2013).

Pengukuran $\mathrm{pH}$ menggunakan metode Ockerman (1983) dengan cara sebelum melakukan pengukuran, $\mathrm{pH}$ meter dikalibrasi dengan larutan buffer $\mathrm{pH} 4$ dan 7, demikian pula elektroda dibilas dengan aquades dan dikeringkan. Sampel daging bagian dada ditimbang seberat $5 \mathrm{~g}$ dan dicampur dengan $25 \mathrm{~mL}$ aquades, kemudian dihaluskan. Elektroda dicelupkan ke dalam sampel dan nilai $\mathrm{pH}$ dapat di baca pada skala yang ditunjukkan oleh angka penunjuk. Pengukuran $\mathrm{pH}$ daging dilakukan saat setelah pengujian residu antibiotic selesai dilakukan

Penanganan saat pemotongan secara syariat agam islam (halal) dengan memotong trachea, oesophagus, vena dan arteri (Prakorso 2012) pemotongan yang dilakukan ditempat pemotongan yaitu menggunakan pisau secara manual oleh penyembelih. Penirisan darah dilakukan selama 3-5 menit, jika pengeluaran darah ini tidak sempurna maka akan terlihat kemerahan dileher, bahu, sayap, kehitaman pada folikel bulu dan jantung berisi darah (DSN 1995)

Setelah darah dikeluarkan lakukan pencelupan ke air panas, pencelupan ini dilakukan dengan air dengan suhu $60{ }^{\circ} \mathrm{C}$ selama kurang dari satu menit. Sedangkan menurut (Cahyono 2013) pencelupan ayam dilakukan dengan menggunakan suhu $50-55^{\circ} \mathrm{C}$ selama 2.5 menit. Setelah itu dilakukan pencabutan bulu dibantu dengan menggunakan mesin pencabut bulu otomatis selama kurang lebih 2 menit. Tahap selanjutnya yang dilakukan setelah pencabutan bulu yaitu pemisahan ayam dari kepala dan cekernya secara manual menggunakan pisau, selanjutnya pengeluaran jeroan juga dilakukan secara manual menggunakan pisau.

\section{KESIMPULAN}

Residu antibiotik golongan aminoglikosida, makrolida, dan tetrasiklin tidak ditemukan pada sampel daging dada, paha dan hati dari sampel yang diambil dari pasar ayam broiler di Kabupaten Pidie Jaya. Kecuali antibiotik golongan penisilin pada sampel daging dada, paha dan hati ayam broiler yang diambil dari pasar Trienggadeng menujukkan adanya residu antibiotik. Ditemukannya residu antibiotik penisilin pada salah satu peternakan di kabupaten Pidie Jaya disebabkan oleh pemberian antibiotik pada ayam selama masa pemeliharaan dengan tujuan pengobatan penyakit dan dipotong sebelum masa withdrawal time (masa henti obat). Kualitas daging ayam broiler yang dijual pada beberapa pasar di Kabupaten Pidie Jaya masih layak untuk dikonsumsi.

\section{DAFTAR PUSTAKA}

[BSN] Badan Standarisasi Indonesia. 2008. SNI 7424:2008 Tentang Metode Uji Tapis (Screening Test) Residu Antibiotik pada Daging, Telur dan Susu Secara Biossay. Jakarta (ID): Badan Standarisasi Indonesia.

[KepMentan] Keputusan Menteri Pertanian. 1994. KepMentan No.806/Kpts/TN.260/12/1994 Tentang Klasifikasi Obat Hewan. Jakarta (ID): Departemen Pertanian.

[SNI] Standar Nasional Indonesia. 2000. Batas Maksimum Cemaran Mikroba dan Batas Maksimum Residu dalam Bahan Makanan Asal Hewan. SNI 01- 6366-2000.

Bahri, S., Masbulan E, Kusumaningsih A. 2010. Proses Praproduksi sebagai Faktor Penting dalam Menghasilkan Produk Ternak yang Aman untuk Manusia. Jurnal Litbang Pertanian. 24 (1).

Cahyono, A 2014 Abattoir dan Tehnik Pemotongan Ternak. Kediri: Fakultas Peternakan Universitas Halu Uleo

Donkor, E.S., M.J. Newman., C.K. Tay., K.D. Dayie., E. Bannerman, O.M. Taiwo. 2011. Investigation into the risk of exposure to antibiotic residues contaminating meat and egg in Ghana. J. Food Control. 22(6): 869873.

Duna, A.A., D.J. Kilpatrick, N.F.S. Gault. 2010. Effect of Postmortem Temperatur on Chiken in Pectorales Major : Muscle Shortening and Cooked Meat Tenderness. J. British Poultry Sci. 34:689-697.

Kirbiš, A. 2010. Microbiological screening method for detection of aminoglycosides, ß-lactams, macrolides, tetracylines and quinolones in meat samples. Slov Vet Res. 44(1/2): 1-8.

Lawrie, R.A. 2009. Meat Science. The $6^{\text {th }}$ ed. Terjemahan. A. Paraksi dan A. Yudha. Jakarta (ID): Penerbit Universitas Indonesia.

Mattjik, A.A., \& I.M. Sumertajaya. 2002. Perencanaan Percobaan dengan Aplikasi SAS dan Minitab jilid I. Bogor (ID): IPB Pr.

Nisha, A.R. 2011. Antibiotic residues a global health hazard. $J$ Vet World Rev. 1(12):375-377.

Ockerman, H.W. 1983. Chemistry Of Meat Tissue. Departement Animal Science. Ohio (US): The Ohio State University The and Ohio Agricultural Resarch and Devolopment Center.

Priyatno, A.H., \& E. Suryanto. 2012. Kualitas Fisik dan Sensoris Daging Ayam Broiler yang Diberi Pakan dengan Penambahan Ampas Virgin Coconut Oil ( VCO). Buletin Peternakan. 34(1):55-63.

Prakorso, RP 2012. Perbandingan Kualitas Karkas Ayam broiler dan ayam kampung. Ilmu Peternakan

Peter TL, Fulton RM, Roberson DK Dan Orth MW. 2002. Effect Of Antibiotics On In Vitro And In Vivo Avian Cartilage Degradation. Avian Diseases 46:75-86.

Soeparno, R.A., Rihastuti, Suharjono. 2011. Dasar Tehnologi Hasil Ternak. Yogyakarta (ID): Gadjah Mada University Pr. hlm 33.

Supriyadi. 2009. Panduan Ayam Broiler Lengkap. Depok (ID): Penebar Swadaya.

Suradi, K. 2009. Perubahan sifat fisik daging ayam broiler 
post mortem selama penyimpanan temperatur ruang. [tesis]. Bandung (ID): Fakultas Peternakan Universitas Padjajaran.

Saniwati, Nuraini, Agustina D. 2015. Studi Residu Antibiotik Daging Broiler yang beredar di Pasar Tradisional Kota Kendari. Fakultas Peternakan Halu Oleo. JITRO VOL. 1. NO 3. Mei. 2015
Van Laack, R., CH. Liu., M. Smith., H. Loveday. 2010. Characteristics of pale, soft, exudative broiler breast meat. Poult Sci. 79(7):1057-1061.

Woteki, C.E., \& J.E. Henney. 2000. Antibiotic resistance in livestock. Di dalam: USDA/HHS Response to the House and Senate Report, USA. 